\title{
Sosiologi Persekolahan
}

\author{
Abdul Malik \\ Universitas Islam Negeri Mataram
}

Naskah diterima 14 Nov 2018, direvisi 17 Des 2018, disetujui 20 Jan 2018

Abstract The development of the school as an educational practice as long as it shows a lot of issues that are wrapped around the school. One of them is the difficulty of school to find recipes to produce the smart and good school output, to build this requires partnership and configuration changes. The configuration is the influence of the school became an interesting study, because it tends to change its effects. The school as the initiator needs to build a coalition that synergistic between schools, families, and communities.

Keywords: school, partnership, changes, Family, the community configuration

Abstrak Perkembangan sekolah sebagai praktek pendidikan selama ini memperlihatkan banyak masalah yang melilit sekolah. Salah satunya adalah kesulitan sekolah menemukan resep untuk menghasilkan output sekolah yang smart sekaligus good, untuk membangun hal ini membutuhkan partnership dan perubahan konfigurasi. Konfigurasi pengaruh dari sekolah menjadi kajian yang menarik, karena cenderung berubah pengaruhnya. Sekolah sebagai inisiator perlu membangun koalisi yang sinergis antara sekolah, keluarga, dan masyarakat.

Kata kunci: sekolah, partnership, perubahan, keluarga, masyarkat konfigurasi

\section{A. PENDAHULUAN}

Sudah menjadi kesadaran bersama bahwa pendidikan adalah poros dari kemajuan suatu bangsa dan negara.Poros pendidikan di Indonesia dikenal ada tiga macam yakni pendidikan keluarga, sekolah, dan pendidikan masyarakat.Selama ini, perdebatan dari 
pemikiran pendidikan adalah bagaimana konfigurasi praksis dari ketiga poros pendidikan ini, walaupun perdebatan ini tidak lebih dari lips service semata.Belum ditemukan secara jelas bagaimana praksisnya konfigurasi tersebut.Pendidikan keluarga dan sekolah misalnya, terlihat berjalan sendiri-sendiri bahkan dewasa ini aktivitas pendidikan itu benar-benar nyata terlihat hanya di sekolah.Keluarga menyerahkan semuanya ke sekolah, itulah sebabnya sekolah menjadi satu-satunya harapan, kecanduan terhadap sekolah semakin menyisihkan peran keluarga (orang tua) sebagi salah satu lokus pendidikan utama.

Lepas dari peran tunggal sekolah sebagai poros pendidikan, perkembangan sekolah sebagai praktek pendidikan selama ini memperlihatkan banyak masalah yang melilit sekolah. Salah satunya adalah kesulitan sekolah menemukan resep untuk menghasilkan output sekolah yang smart sekaligus good, untuk membangun hal ini membutuhkan partnership dan perubahan konfigurasi. Konfigurasi pengaruh dari sekolah menjadi kajian yang menarik, karena cenderung berubah pengaruhnya.Sekolah sebagai inisiator perlu membangun koalisi yang sinergis antara sekolah, keluarga, dan masyarakat.

Banyak riset membuktikan bahwa di negara berkembang termasuk Indonesia dampak keluarga terhadap pendidikan masih sangat kecil ketimbang dampak sekolah. Sekolah sukses 50\% dari dukungan keluarga dan berbagai pihak lain, persoalan kemudian adalah bagaimana membangun konfigurasi dan koalisi edukatif, sehingga tidak terlihat berjalan sendiri-sendiri. Besar dan luasnya dampak sekolah sangat dipengaruhi oleh seberapa luas dan intensnya intervensi faktor-faktor eksternal dalam pengembangan sekolah itu sendiri.Faktor eksternal di sini adalah keluaraga dan kebijakan berupa regulasi pro sekolah yang dibangun dari paradigma konfigurasi tersebut. Kita tidak memilik kebijakan sekolah home visit misalnya dan otoritas guru yang kuat dan luas seperti negara-negara maju.

Dalam hal ini sekolah perlu dikembangkan sharing, caring, and learning, untuk itu perlu dibangun komunikasi untuk 
mengembangkan dialog. Sekolah harus membangun kemampuan berkomunikasi dan mendorong siswa untuk melakukan hal-hal yang mengembangkan potensi diri secara optimal.Sekolah sering kali tidak dapat memberikan hal-hal yang dibutuhkan oleh siswa, misalnya bagaimana peran sekolah dalam mengatasi kesulitan belajar, kemudian tidak sedikit sekolah yang tidak memberikan pengetahuan atau keterampilan sosial dalam menghadapi kehidupan sehari-hari.

Artikel ini membahas mengenai lingkungan sekolah dalam perspektif sosiologis.Sekolah sebagai inisiator perlu membangun koalisi yang sinergis antara sekolah, keluarga, dan masyarakat.Sekolah juga merupakan tempat praktek pendidikan selamauntuk menghasilkan output sekolah cerdas, bagus, demikian membangun memerlukan partnership dan perubahan konfigurasi.

\section{B. PEMBAHASAN}

\section{Fungsi dan Peran Sekolah}

Sekolah kalau ditinjau dari peran dan jenisnya ada tiga pola kecenderungan menurut Suyata, pertama bahwa sekolah can do anything, everything, and anywhere (Suyata, 2014:8). Kecenderungan ini, sekolah dianggap dan diyakini sebagai lembaga serba bisa dengan dukungan di luar seperti keluarga, masyarakat, dan pemerintah. Anak cerdas dan baik hanya akan bisa dibentuk di sekolah, nilai-nilai kebajikan hanya bisa dibangun disekolah. Cara pandang ini menurut Alma Haris dalam karyanya School Improvement menjadikan sekolah itu adalah harapan (school is hope) (Haris, 2002: 12). Pandangan ini tidak sepenuhnya salah melihat pola relasi keluarga, masyarakat, dan sekolah hari ini yang tidak sinergetik. Artinya apa yang menjadi wajib baik di sekolah tidak menjadi wajib baik dirumah, begitu juga sebaliknya atau apa yang menjadi model di rumah tidak menjadi model di sekolah dan sebaliknya, sehingga sekolah can do anything, everything, and anywhere akan dapat diwujudkan ketika mendapatkan dukungan dari masyarakat. 
Peranan sekolah dalam hal ini, diharapkan dapat melakukan segala hal jika didukung oleh institusi lain. Ciri dari sekolah seperti ini, menurut Suyata adalah output lulusan jauh lebih baik dari pada input, ini menunjukan bahwa peran dan fungsi sekolah dapat melakukan segalanya terhadap anak didik. Peran sekolah di atas, merupakan paham modern dari aliran struktur fungsional, walaupun setelahnya mendapatkan kritikan dari paham postmodern.Seperti yang dikemukakan oleh Anderson dalam Suyata, bahwa sekolah pada dasarnya lemah secara institusi tetapi ketika didukung oleh masyarakat menjadi sangat kuat (Suyata, 2014:23).

Kedua, school can do nothing, peranan sekolah dalam pandangan ini, bahwa sekolah hanya meneruskan apa yang sudah ada di keluarga, sehingga buat apa sekolah? Hal ini senada dengan apa yang dipopulerkan oleh Ivan Illich dalam bukuya "Deschooling Society". Illich mengatakan, mengapa kita harus menghapuskan sekolah?(Illich, 1970:10).Bagi Illich sekolah hanya melembagakan nilai-nilai yang mengarah pada polusi fisik, polarisasi sosial, dan impotensi psikologis.Fanatisme terhadap sekolah memungkinkan masyarkat untuk dieksploitasi lebih.Di seluruh dunia, sekolah memiliki efek anti nilai-nilai pendidikan pada masyarakat, kegagalan-kegagalan yang ditunjukan sekolah merupakan bukti pendidikan itu sangat mahal, kompleks, dan hampir merupakan tugas yang tidak mungkin dilakukan.Itulah kenapa dikatakan bahwa sekolah tidak bisa berbuat banyak dalam mengembangkan potensi anak didik. Pandangan ini meyakini bahwa semua anak memiliki kemampuan yang sama sejak lahir, sehingga sekolah tidak merubah apa-apa. Anak yang pintar dan baik di sekolah disebabkan karena anak sudah punya bakat bawaan dan sudah pintar dan baik di rumah, artinya input anak sudah bagus sehingga outputnya juga bagus, dengan demikian sekolah sesusngguhnya tidak berbuat banyak dalam keberhasilan peserta didik.

Ketiga, school can do something, dalam konteks ini sekolah merancang secara tepat berbagai aktivitas belajar, dalam beberapa hal sekolah dikelola secara kondisional, sehingga modifikasi 
terjadi pada sekolah dan program yang dikembangkan lebih terbatas. Pandangan bahwa sekolah bisa melakukan beberapa hal walaupun terdapat keterbatasan di dalam peran tersebut.Keterbatasan peranan sekolah ini dipopulerkan Harvard University dengan istilah the limit of schooling. Schooling limits hanya mampu menawarkan aspek-aspek tertentu pada anak-anak tertentu pula, misalnya sekolah hanya dapat mengembangan aspek kognitif siswa.

Perubahan di sekolah seharusnya dimulai dengan mencari data tentang value dan behavior, disisi lain pemahaman tentang fungsi sekolah harus dimiliki oleh para pengelola dan pendidik. Sebagai contoh, fungsi sekolah TK adalah masa transisi dari dunia keluarga menuju dunia sekolah, dari individu menuju kolektivitas.Fungsi sekolah direspon berbeda oleh setiap negara, sebagai gambarannya Amerika cenderung melayani individual dan kelompok rasio kecil, sementara Jepang cenderung melayani kolektivitas.Bagaimana dengan Indonesia? Ada banyak teori fungsi dan peran sekolah yang dikembangan selama ini, John Holt (1972) misalnya, dalam karya "Freedom and Beyond" menyajikan kajian teoritis dan praktis dari konsep reformasi pendidikan melalui pembelajaran terbuka (Holt,1972:23). Menurut Holt, sekolah berfungsi untuk melaksanakan pembelajaran terbuka. Pembelajaran terbuka yang dimaksud adalah pembelajaran yang harus mempertimbangkan konsepsi tentang sifat dasar anak, bagaimanapun secara dasariah setiap anak cerdas, energik, memiliki rasa ingin tahu, ingin belajar dengan baik oleh karena itu anak-anak tidak harus diakali, dipikat, dan dipaksa untuk belajar.

Bagi John Holt, fungsi sekolah ditentukan oleh sifat dasariyah anak dan kebutuhan anak yang diniatkan untuk melayani anak. Pandangan Holt ini sesuai dengan pandangan John Dewey (1929), yang melihat tujuan pendidikan sebagai pertumbuhan dan menempatkan tujuan pendidikan dalam proses pendidikan itu sendiri (Dewey,1929:25). Praktik sekolah selama ini, menafikan fungsi kemanusiaannya dengan melayani agen indoktrinasi yang melemahkan nilai-nilai yang diidentifikasikan oleh kelompok 
dominan di masyarakat. Kendatipun demikian, secara empiris penulis belum menemukan penerapan ide John Holt dan Ivan Illich secara total dalam pendidikan. Kritikan kedua tokoh ini, merupakan salah satu cara untuk melakukan humanisasi pendidikan yang melayani tumbuh kembang siswa sesuai bakat kemanusiaannya, bukan melayani birokrasi pendidikan dan menjadikan siswa sebagai obyek pekerjaan.

Lepas dari pandangan di atas, bagaimana sesungguhnya sekolah menjalankan fungsinya?Masalah ini merupakan kajian yang penting untuk dianalisis baik secara folosofis, kebijakan, teori, maupun praktiknya. Eksistensi sekolah perlu untuk dikaji kembali dengan memperhatikan beberapa prioritas program, sebagaimana dijelaskan oleh Suyata bahwa yang paling awal bagimana sekolah dapat membawa masyarakat ke sekolah dan bagiamana sekolah dibawa ke masyarakat, dan selanjutnya bagaimana menentukan manfaat sekolah bagi masyarakat serta bagaimana masyarakat memajukan sekolah. Terkait dengan hal ini, tidak berlebihan kemudian perbaikan sekolah dapat juga dimulai dari pertanyaan John Holt, how children fail ?danhow children learn ?. Berikut ini akan uraikan beberapa mazhab sekolah dan type-type sekolah, dengan harapan ditemukan paradigama dalam perbaikan sekolah itu sendiri.

\section{Mazhab Persekolahan}

Ada dua mazhab besar dalam gerakan perbaikan sekolah, pertama gerakan sekolah efektif (school effectiveness movement), kedua gerakan sekolah bermutu (school improvement movement) atau juga dikenal dengan quality school movement. Pada dasarnya ada banyak teori yang menyoroti tentang bagaimana perbaikan sekolah itu dilakukan, akan tetapi dalam tulisan ini dibatasi dalam dua hal di atas.

Kedua mazahab gerakan perbaikan sekolah di atas, kendati memiliki perbedaan paradigma dan proses akan tetapi memiliki tujuan yang sama yakni mencari formula perbaikan sekolah efektif secara internasional melalui eksperimen dan dialog. Bagaimana 
sekolah menjadi efektif, apa determinan sekolah efektif adalah pertanyaan yang mendasar dalam kedua mazhab ini. Dua mazhab ini meyakini bahwa dalam perbaikan sekolah tidak ada standar baku. Oleh karen itu, jika kedua mazhab tersebut dinilai sebagai idiologi dalam perbaikan mutu memerlukan dialog teori untuk menentukan dasar bagi perbaikan mutu, karena setiap idiologi dalam perbaikan mutu memiliki kelebihan dan kekurangan.

Organisasi internasional seperti ICSEI (International Congrress for School Effectiveness and Improvement) misalnya, baru-baru ini melekasanakan perhelatan tahunan ke-27 di Yogyakarta, dengan tema "Redefining Education, Learning, and Teaching in the 21st Century: The Past, Present and Future of Sustainable School Effectiveness", Konferensi tahunan inidirancang untuk mengangkat sejumlah isu-isu aktual dan penting bagi para peneliti, praktisidan pembuat kebijakan guna mendefinisikan kembali pendidikan atas perubahan konsepbelajar-mengajar bagi anak didik di abad ke-21 ini ke depan. Organisasi international ini mencoba mencari determinan gerakan sekolah berkualitas dan sekolah efektif sebagai bentuk perbaikan atas problem pendidikan dewasa ini.

Praktek pendidikan di Indonesia cenderung tidak jelas, hal ini disebabkan dalam mengembangkan pendidikan tidak membedakan antara gerakan sekolah efektif dengan gerakan sekolah bermutu. Dalam hal ini, praktek kebijakan pendidikan di Indonesia cenderung merupakan "pinjaman" atau "borrowing"dari luar, akibatnya teori, praktik, dan kebijakan pendidikan di Indonesia sering tumpang tindih bahkan tidak sesuai dengan lokus dan budaya yang ada. Pada akhirnya praksis pendidikan sering kali tidak kontekstual dan sulit membudaya apalagi menciptakan budaya.

Pembangun pendidikan di Indonesia masih harus mempertimbangkan prinsip gerakan yang dipilih, apakah menekankan pada school effectiveness atau school improvement.Dengan kompleksitas masalah pembangunan dan kondisi sosial budaya yang beragam seharusnya gerekan school improvement menjadi alternative kebijakan yag harus dipikirkan 
secara komprhensip-integratif oleh pemerintah. Hal ini penting, mengingat persoalan pendidikan di Indonesia cukup komplek, berbagai upaya sudah dilakukan oleh pemerintah untuk mengatasi masalah pendidikan baik dalam tatanan struktur maupun kultur. Mazhab persekolahan yang diwakili oleh dua gerakan perbaikan sekolah merupakan salah satu usaha rill dalam dunia pendidikan. Berikut ini perbedaan dari gerakan school effectiveness movement dan school improvement movement.

School Effectiveness Movement,Gerakan sekolah efektif didasarkan pada sulitnya mewujudkan pembelajaran efektif, misalnya guru efektif itu adalah seorang yang mampu meyakinkan semua siswanya untuk melakukan pekerjaan yang bermutu di sekolah. Pekerjaan kualitas adalah bekerja sampai kapasitas maksimal, bukan sambil lalu apalagi santai. Fenomena kegagalan sekolah selama ini, seperti angka putus sekolah, nila ujian rendah, kualitas proses rendah dan lain-lain pada dasarnya disebabkan karena kegagalan guru, kepala sekolah, dan siswa mengeluarkan upaya maksimal tersebut.

Gerakan sekolah efektif, lebih cenderung berorientasi standar produk, misalnya UN (ujian nasional) sebagai ukuran keberhasilan anak di sekolah. Terkait dengan kebijakan misalnya, gerakan sekolah efektif ini lebih cenderung menggunakan pendekatan one size fits for all untuk memecahkan kompleksitas masalah pendidikan. Akibatnya suatu kebijakan tidak selalu berhasil untuk semua sekolah. Kemudian gerakan ini pula lebih berorientasi scientific approach, kebijakan satu arah, pendekatan kuantitatif, perkembangan sistem itu penting, fokus pada stadarisasi, birokratif, hubungan formal, behavioristik, peran teori cenderung statis.

School Improvement Movement, Gerakan sekolah bermutu pada dasarnya reaksi dari gerakan sekolah efektif yang terlalu positifistik. Pelaksanaan gerakan ini bersifat kontekstual, disamping itu orientasi umum dari gerakan sekolah bermutu ini adalah human approach, tergantung kondisi sekolah, satu kebijakan untuk satu msalah, orientasi komunitas, pendekatan 
kualitatif, orientasi proses, perkembangan sistem itu penting, kulturalis, hubungan informal, konstruktivistik, dan peran teori tidak final.

Gerkan ini meyakini bahwa semuanya dapat diperbaiki, sehingga perbaikan sekolah itu selalu diidentikan dengan perbaikan mutu berkelanjutan. Perbaikan mutu dalam pandangan gerakan ini harus dimulai dari dalam sekolah itu sendiri oleh karena itu, pendekatan kultur dalam gerakan ini menjadi tujuan utama dari setiap unsur-unsur perbaikan sekolah. Seperti kualitas kultur sekolah, guru, siswa, fasilitas, dan kualitas manajemen.

\section{Paradigma perbaikan sekolah}

Ada banyak definisi tentang perbaikan sekolah dan berbagai interpretasi perbaikan sekolah sebagai proses. Seperti yang dikatakan oleh Haris (2002), penetapan perbaikan sekolah adalah usaha sadar,sistimatis,dan berkelanjutan untuk perubahan kondisi belajar dan pendidikan yang lebih efektif sekaligus bermutu. Terkait dengan ini, ada dua hal yang digunakan dalam perbaikan sekolah menurut Hopkins (1996), dalam bukunya "Towards a theory for school improvement"pertama; makna pandangan umum yang berhubungan dengan upaya untuk membuat sekolah menjadi tempat yang baik bagi belajarnya siswa, kedua; bahwa perbaikan sekolah sebagai suatu strategi bagi perubahan pendidikan yang memperkaya hasil belajar siswa maupun memperkuat kapasitas sekolah dalam merubah manajemen sekolah (Hopkins, 1996:4). Pandangan Hopkins di atas, menguatkan bahwa definisi perbaikan sekolah adalah sebagai proses perubahan budaya sekolah itu sendiri, oleh karena itu sekolah ditempatkan sebagai pusat perubahan dan guru sebagai bagian instrinsik dari proses perubahan itu.

Selain itu juga Hopkins menekankan bahwa untuk perbaikan sekolah guru perlu berkomitmen untuk berada dalam proses perubahan, sehingga perbaikan sekolah itu harus terjadi secara menyeluruh, problem guru adalah pengembangan guru berdasarkan pengembangnan sekolah. Merujuk dari filsafat 
pendidikan Waithhead, sesungguhnya fungsi sekolah adalah membangun kearifan dan kecerdasan, sehingga pendidikan masa lalu mengutamakan kebajikan sebagai outputnya. Sementara sekolah sekarang membangun kecerdasan semata, perbaikan sekolah harus berorientasi membangun keduanya, sehingga anak tidak hanya cerdas tapi juga baik (Gutek, 1974:12).

Perbaikan sekolah harus didasari oleh adanya kemauan untuk berubah seperti yang ditekankan oleh Hopkins di atas. Terkait dengan hal ini, menurut Ben Levin ada empat kunci pendukung perubahan sekolah;Engagement and commitment by the adults in the system, Effective collective processes for educators to continue to improve their practice (often referred to as professional learning communities), Coherent and supportive system policies and practices, Appropriate allocationof recourses (Levin, 2012:120).

Pandangan Levin di atas, walaupun pada sekolah tertentu faktor-faktor tersebut ada perbedaannya, tetapi banyak dari elemen-elemen dasar tersebut yang sama. Keempat hal di atas, menurut menteri pendidikan New Zealand seperti yang dikutip oleh Levin harus didukung oleh pola kepemimpinan integratif.Kepemimpinan integratif yang dimkasud adalah kepemimpinan yang mensinergikan antara kemampuan memimpin dan manajerial (lead and manager).Sayangnya, dalam tulis ini tidak cukup ruang untuk menguraikan bagaimana peran kedua hal ini dalam perubahan sekolah. Kendatipun demikian, ada lima karakteristik kepemimpinan sekolah menurut Levin, pertama, mempertahankan tujuan dan harapan, kedua; strategic resourcing, ketiga; perencanaan, koordinasi, dan evaluasi pengajaran dan kurikulum, keempat; promosi dan partisipasi di dalam pengembangan dan pengajaran guru, kelima; memastikan ketertiban dan lingkungan pendukung (Levin, 2012:177).

\section{Budaya Sekolah}

Dalam literatur perbaikan sekolah, sekolah dipadang sebagai budaya organic dan dinamis. Asumsi kunci dalam literatur ini adalah strategi perbaikan yang dapat mengakibatkan perubahan 
kultur sekolah dan kepemimpinan yang memiliki bagian penting dalam mendefinisikan dan membentuk budaya. Adapun type-type budaya sekolah yang cenderung mendukung perbaikan adalah bersifat kolaboratif, memiliki hubungan kerja dengan perguruan tinggi, dan memiliki iklim untuk berubah. Mempertahanan iklim positif untuk perubahan adalah prasyarat yang penting untuk perbaikan sekolah. Suasana ini harus memfasilitasi belajar dalam organisasi dan mendukung mereka yang terlibat dalam belajar.

Sementara di sisi lain, perbaikan sekolah tidak lepas dari patologi sekolah sebagai sisi gelap yang terjadi dalam budaya sekolah itu sendiri. Gerakan perbaikan sekolah telah menyoroti bagaimana patologi sekolah itu terjadi dan beberapa jenis budaya negatif yang dapat mempengaruhi pengembangan dan kinerja sekolah. Penelitian telah menunjukan bahwa sekolah yang tidak efefktif, memiliki budaya khusus dengan ciri-ciri tidak berfungsinya hubungan antara staf serta cukup fokus pada mengajar dan belajar.

Sebagai bahan perbandingan, berikut ini akan diuraikan beberapa type sekolah; Sekolah baik, Studi tentang peningkatan sekolah telah menunjuka bawa mereka cenderung menjadi organisasi yang baik dengan sistem yang efisien untuk merekam dan meninjau kemajuan. Mereka menyediakan kesempatan staff untuk kerjasama tetapi tetap mengimbangi antara aktivitas pemeliharaan dan aktivitas pengembangan.

Sekolah gagal, Sekolah gagal yang dimaksud adalah visibilitas yang rendah pada pengembangan, rendah pada pemeliharaan, miskin dalam manajemen tugas harian, kemudian dalam pemecahan masalah lebih cenderung reaktif dari pada proaktif, kurangnya peran kepemimpinan dalam orgnaniasi sekolah, tidak memiliki orintasi pada perguruan tinggi dan tidak memiliki tujuan, perencanaan, dan visi yang jelas untuk diartikulasikan.

Sekolah Terjebak, sekolah terjebak adalah mereka yang melakukan semua kegiatan pemeliharaan yang diperlukan tapi mengabaikan peningkatan pekerjaan. Sekolah ini tidak jelas gagal karena nampaknya mereka bisa menjalankan secara 
efektif.Sekolah seperti ini terlihat tidak ada masalah dan bahkan terkesan maju padahal kenyataannya jalan di tempat dan penuh dengan masalah.

Sekolah Dinamis, Sekolah dinamis cenderung pada pendekatan inovatif dengan antusiasme yang besar dan dipandang oleh orang di luar sekolah dengan cara yang sangat positif. Selain itu sekolah dinamis juga disebut sebagai sekolah yang hidup, menarik, dan respek terhadap masalah yang ada, sehingga sekolah tipe ini cenderung mengikuti perkembangan yang ada disekitar.

\section{KESIMPULAN}

Untuk sementara ini, tidak ada jawaban yang tepat untuk memperbaiki sekolah, akan tetapi setidaknya menurut interntional hand book karya Toensen, bahwa tingkat kemajuan sekolah itu berbeda-beda, oleh karena itu perbaikan sekolah harus dilihat dari perbedaan kebutuhan sekolah, perbedaan konteks dan lingkungan atau ekosistemnya, sehingga di sini perlu dibangun satu strategi perbaikan yang dipandu oleh teori dalam perbaikan sekolah.

Gerakan perbaikan sekolah adalah gerakan dunia untuk mencari format sekolah efektif dan bermutu, untuk melengkapi penutup dari tulisan ini, penulis mengakhiri dengan beberapa pertanyaan reflektif-kritis sebagai frame dalam perbaikan sekolah. pertama;bagaimana anda mendefiniskan perbaikan dalam konteks sekolah anda? Kedua; bukti apa yang anda butuhkan untuk dikumpulkan yang menunjukan bahwa perbaikan sekolah sedang berlangusung? Ketiga; siapa yang menjadi pemain kunci dalam menjamin perbaikan sekolah?Keempat; apa tantangan yang dihadapi oleh sekolah anda dalam konteks perbaikan? 


\section{DAFTAR PUSTAKA}

Dewey, J. 1929. Experiences and Nature. London. Ruskin House

Gutek, G.L. 1974. Philisophical alternatives in education. USA. Colombus

Haris, A. 2002. School Improvement. London. Rouledge

Holt, J. 1972. Freedom and Beyond. New York. Penguin Education

Hopkins, D. 1996. Towards a theory for school improvement. London. Cassell

Illich, I . 1970. Descoholing Society. New York. Rouledge

Levin, B. 2012. How to change 5000 schools, a practical and positive approach for leading change at every level. USA. Harvard Educaion Press

Suyata. 2014. Sketsa teori persekolahan. Yogyakarta: UNY Press 